\title{
EKSPLORASI ETNOMATEMATIKA KONSEP POLA BILANGAN DALAM PERMAINAN TRADISIONAL
}

\author{
Anisa Laela Ramadhina ${ }^{1}$, Citra Septiana ${ }^{2 *}$, Melinda Pebrianti ${ }^{3}$, Wahidin ${ }^{4}$ \\ 1, 2,3,4Program Studi Pendidikan Matematika, Universitas Muhammadiyah Prof. DR. HAMKA \\ Jalan Tanah Merdeka No. 20, Rambutan, Kec. Ciracas, Kota Jakarta Timur, DKI Jakarta, Indonesia \\ Submitted: July 04, 2021 \\ e-mail: ${ }^{2}$ citraseptiana49@gmail.com; \\ Revised: October 28, 2021 \\ Accepted: November 05, 2021 \\ corresponding author*
}

\begin{abstract}
Abstrak
Penelitian ini bertujuan untuk mempelajari keterkaitan antara matematika dan budaya di Indonesia, salah satunya adalah permainan tradisional Nasi Goreng Kecap dan Mejikuhibiniu. Penelitian ini penting karena mengajarkan siswa untuk melihat kegiatan dunia nyata dengan jelas dengan diintegrasikan ke dalam ide-ide matematika. Penelitian ini menggunakan pendekatan etnografi dan studi pustaka (kajian literatur) yang merupakan jenis penelitian kualitatif. Hasil dari penelitian ini adalah permainan tradisional Nasi Goreng Kecap dan Mejikuhibiniu memuat konsep pola bilangan, yang dapat dikembangkan dalam suatu rancangan pembelajaran materi pola bilangan, sehingga dapat mengubah paradigma siswa bahwa matematika yang masih dianggap ilmu abstrak menjadi matematika yang lebih menyenangkan.
\end{abstract}

Kata Kunci: etnomatematika, permainan tradisional, pola bilangan

\section{EXPLORATION OF NUMBER PATTERNS ETHNOMATHEMATICS CONCEPTS IN TRADITIONAL GAMES}

\begin{abstract}
This study aims to study the relationship between mathematics and culture in Indonesia, one of which is the traditional game of Nasi Goreng Kecap and Mejikuhibiniu. This research is considered important because it teaches students to see real-world activities clearly by being integrated into mathematical ideas. This research uses an ethnographic approach and a library study (literature study) which is a type of qualitative research. The result of this research is that the traditional game Nasi Goreng Kecap and Mejikuhibiniu contains the concept of number patterns, which can be developed in a learning design for number pattern material so that it can change the student's paradigm that mathematics is still considered abstract science to be more fun mathematics.
\end{abstract}

Keywords: ethnomathematics, traditional games, number patterns

\section{Pendahuluan}

Pemahaman masyarakat akan pentingnya mengelola dan melindungi warisan budaya kini sudah semakin tinggi. Faktanya, banyak pecinta dan pemerhati pusaka yang meyakini bahwa kekayaan budaya bukan hanya warisan Bangsa Indonesia, tetapi juga peninggalan Bangsa Indonesia (Tanudirjo, 2003). Pendidikan dan budaya adalah dua unsur yang tidak dapat dihindarkan dalam kehidupan sehari-hari, hal ini selaras dengan budaya merupakan kesatuan utuh dan menyeluruh yang berlaku dalam suatu masyarakat dan pendidikan merupakan kebutuhan mendasar bagi setiap individu dalam masyarakat (Lubis et al., 2018). Pembelajaran berbasis budaya merupakan model pembelajaran yang memfokuskan pada pengintegrasian aktivitas peserta didik dari beragam latar belakang budaya yang berbeda ke dalam proses pembelajaran (Fahrurrozi, 2015).

Matematika selama ini dipandang sebagai ilmu abstrak, maka seorang guru harus menyadari hal tersebut dan menggunakan teknik yang dapat menstimulasi pembelajaran. Tantangan dalam mengajar adalah bagaimana mengekspos peserta didik untuk menghubungkan praktik dunia nyata dan ide-ide matematika, antara visual-intuitif dan rasional-logis (Verner et al., 2019). Salah satu caranya yaitu dengan belajar dan memahami apa itu etnomatematika yang merupakan implementasi matematika dalam suatu kelompok budaya (Nusantara \& Rahardjo, 2017). Etnomatematika juga mengulas tentang bahasa, nilai, perilaku, pengetahuan, hingga penerapan kelompok budaya dalam suatu lingkungan tertentu (Leal Vasquez, 2017). Di samping itu, (Dahlan \& Permatasari,

Copyright $(\odot$ Authors. This is an open access article distributed under the Attribution-NonCommercial- 
2018) membuktikan bahwa pengetahuan matematika peserta didik dapat disediakan melalui bahan ajar berbasis etnomatematika. Dengan demikian, integrasi matematika dengan berbagai budaya serta penerapan kelompok budaya seperti bahasa, nilai, dan perilaku dalam pembelajaran di kelas, menjadi salah satu jawaban dari tantangan pembelajaran matematika di era saat ini.

Pembelajaran berbasis budaya dapat dibedakan menjadi tiga macam, yaitu belajar tentang budaya, belajar dengan budaya, dan belajar melalui budaya. Contoh salah satu alternatif melakukan kombinasi pembelajaran untuk mengoptimalkan hasil belajar, diantaranya adalah menerapkan pembelajaran berbasis budaya. Sebelum menerapkan budaya dalam pembelajaran, yang terpenting adalah memahami, memahami dan mendalami budaya itu sendiri. Salah satu budaya yang menarik dan menarik yang dapat kita pahami, pahami dan jelajahi adalah permainan tradisional (Munawaroh, 2017; Rusiana \& Nuraeningsih, 2016).

Nasi goreng kecap (NGK atau Tong Tong Galitong Ji) merupakan salah satu permainan tradisional khas Malang. Nasi goreng kecap adalah naga, singa, gorila, lalat, kelelawar dan capung. Permainan ini dimainkan oleh 2 sampai 6 pemain. Ini mencakup lima tahap. Pada tahap kelima, merupakan penentuan bilangan yang akan dioperasikan dengan bilangan pokok (Rosikhoh \& Abdussakir, 2020). Selain nasi goreng kecap, ada permainan tradisional yang masih dimainkan pada masa kini yaitu permainan mejikuhibiniu. Mejikuhibiniu adalah permainan tradisional khas Sunda yang dapat menampung hingga tujuh orang. Setiap peserta dapat memilih satu. Merah, oranye, kuning, hijau, biru, nila dan ungu. Peserta tidak bisa memilih warna yang sama dengan peserta lainnya. Setelah memilih warna yang sesuai, peserta dapat memulai permainan. Seperti pada ABC 5 dasar, peserta dapat melempar rangkaian jari dan mengulangi hitungan me-ji-ku-hi-bi-ni-u hingga semua jari dihitung.

Jika skor berakhir dengan "ME", pemain yang memilih warna merah berhak keluar (lolos). Jika berakhir dengan hasil "JI", maka pemain yang memilih warna jingga berhak keluar (lolos), begitupun dengan "KU", "HI", "BI", "NI", dan "U" maka para pemain berhak keluar jika berakhir pada suka kata tersebut, hingga tersisa 1 orang pemain. Jika hanya tersisa satu orang, semua peserta melepas jari dengan bebas dengan hitungan "BOM-BAS-TER-WER-WIT". "BOM" artinya hukuman dengan pukulan ditangan, "BAS" artinya hukuman bebas, "TER" adalah hukuman yang memutar lengan pemain yang kalah, "WER" yang berarti hukuman jewer, dan "WIT" adalah hukuman berupa cubit. Setiap tahap dalam kedua permainan tersebut menggunakan jari-jari yang diulurkan secara bebas oleh pemain. Karena kedua permainan tersebut para pemain mengulurkan jarijarinya secara bebas tanpa ada ketentuan. Setelah semua pemain mengulurkan jari, maka permainan dimulai dengan menunjuk tiap jari yang diulurkan sambil mengucap kata perkata. Tiap suku kata mewakili satu jari. Suku kata pada jari terakhir menjadi acuan untuk mengeliminasi pemain. Dengan demikian, kedua permainan tersebut memiliki unsur keterkaitan pola bilangan dengan setiap suku kata yang terdapat di dalamnya.

Beberapa penelitian terkait etnomatematika dalam permainan tradisional. (Rohmatin, 2020) Etnomatematika permainan tradisional congklak sebagai teknik belajar matematika. (Susanti, 2020) Eksplorasi Etnomatematika Konsep Operasi Hitung dalam Permainan Tradisional Kempreng. Eksplorasi Etnomatematika Pada Permainan Tradisional Kelereng (Pratiwi \& Pujiastuti, 2020). Etnomatematika Pada Permainan Tradisional Engklek Beserta Alatnya Sebagai Bahan Ajar (Aprilia et al., 2019). Pembelajaran Pola Bilangan melalui Permainan Tradisional Nasi Goreng Kecap (Rosikhoh \& Abdussakir, 2020).

Berdasarkan uraian di atas, terlihat bahwa etnomatematika dalam ranah permainan tradisional dapat digunakan sebagai sumber belajar bagi peserta didik yang merupakan suatu hal menarik untuk diungkap dalam suatu penelitian. Hal itu tidak menutup kemungkinan bahwa permainan yang sering dilakukan oleh peserta didik akan menjadi sumber belajar matematika yang bermakna. Untuk mengeksplorasi permainanpermainan yang sering dilakukan oleh peserta didik, maka perlu dilakukan pengkajian lebih lanjut dalam bentuk penelitian. Dalam hal ini peneliti mengangkat masalah penelitian dengan judul "Eksplorasi Etnomatematika Konsep Pola Bilangan dalam Permainan tradisional".

\section{Metode Penelitian}

Penelitian ini dilaksanakan di Babelan, Kab. Bekasi Jawa Barat. Penelitian ini merupakan penelitian kualitatif guna mengungkap dan memperoleh informasi secara menyeluruh dan mendalam (Prahmana, 2017). Dalam prosesnya penelitian ini menggunakan pendekatan etnografi dengan teknik pengumpulan datanya terdiri atas dua bagian yaitu pengumpulan data pustaka yang diperoleh dari studi kepustakaan serta pengumpulan data lapangan yang terdiri dari observasi dan dokumentasi. Observasi dan dokumentasi dilakukan untuk memperkuat data yang diperoleh dari studi 
kepustakaan. Kemudian data di analisis menggunakan teknik triangulasi data.

\section{Hasil dan Pembahasan}

Pola adalah suatu susunan yang mempunyai bentuk teratur dari bentuk pertama ke bentuk selanjutnya. Sedangkan bilangan adalah sesuatu yang digunakan untuk menunjukkan kuantitas dalam bentuk tanda atau lambang yang biasa disebut angka. Sehingga dapat dikatakan bahwa pola bilangan adalah susunan angka-angka yang mempunyai bentuk teratur dari bentuk pertama ke bentuk selanjutnya (Abdur Rahman As'ari et al, 2017).

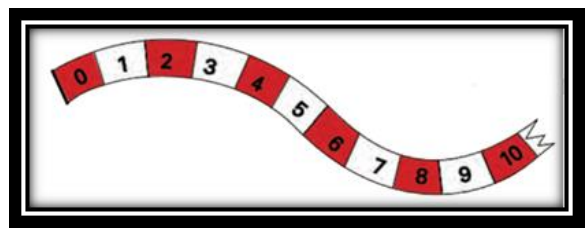

Gambar 1. Pola Barisan Bilangan Dua Warna

Matematika masih dianggap sebagai mata pelajaran yang sulit bagi sebagian siswa sebab matematika adalah ilmu pengetahuan yang mengkaji objek-objek abstrak. Namun di lain sisi matematika memiliki keistimewaan yaitu matematika merupakan ilmu yang menjadi induk dari semua pengetahuan atau dengan kata lain matematika menjadi sumber dari ilmu yang lain. Hal ini berarti bahwa matematika tidak hanya sekadar mengkaji objek abstrak, namun juga dapat digunakan dalam ilmu lain serta terintegrasi dalam kehidupan sehari-hari. Upaya yang dapat dilakukan untuk mengurangi stigma negatif siswa terhadap matematika adalah dengan cara mengintegrasikan matematika ke dalam dunia nyata, salah satunya adalah dengan mengintegrasikan matematika dalam budaya. Tingasti dalam (Misnasanti et al., 2018) mengatakan bahwa budaya yang merupakan kearifan lokal dapat digunakan menjadi sumber belajar.

Dalam hal ini, kearifan budaya lokal pada permainan tradisional Nasi Goreng Kecap sebagai sumber pengetahuan dan sarana penyampaian materi pola bilangan. Secara khusus, penelitian ini hanya menggunakan bagian kedua dari permainan tradisional Nasi Goreng Kecap di integrasikan ke dalam materi pola bilangan siswa kelas delapan SMP. Melalui integrasi permainan tradisional Nasi Goreng Kecap, kecintaan terhadap budaya dan saling menghargai melalui interaksi dapat ditumbuhkan.

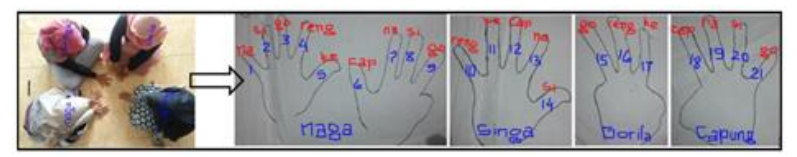

Gambar 2. Cara Memainkan Permainan Nasi Goreng Kecap (Rosikhoh \& Abdussakir, 2020)
Tahap kedua permainan NGK dimulai dengan masing-masing pemain menjulurkan jari dengan bebas, seperti terlihat pada Gambar 2. Menurut Gambar 2, naga, singa, gorila dan capung merentangkan 9 jari, 5 jari, 3 jari, dan 4 jari. masing-masing. Pemain mulai menunjuk dengan jarinya yang terulur dan berkata "nasigorengkecap". Setiap suku kata mewakili jari. Setelah proses penamaan selesai, suku kata terakhir adalah "go", yang berarti gorila harus meninggalkan permainan. Jika diperhatikan, setiap nama berubah menurut pola yang biasa, yaitu ada 6 nama yang berdekatan dengan nama yang sama.

Tabel 1. Pola Barisan Bilangan Permainan Nasi

\begin{tabular}{|c|c|c|c|}
\hline \multicolumn{4}{|c|}{ Goreng Kecap } \\
\hline $\begin{array}{l}\text { Nasi } \\
\text { Goreng } \\
\text { Kecap }\end{array}$ & $\begin{array}{c}\text { Bany } \\
\text { ak } \\
\text { jari }\end{array}$ & Bentuk umum & $\begin{array}{l}\text { Kompetensi } \\
\text { Dasar (KD) }\end{array}$ \\
\hline Naga & $\begin{array}{l}1,7 \\
\ldots \\
\end{array}$ & $\begin{array}{c}a=1 \\
b=6 \\
U n=1+(n-1) 6\end{array}$ & \multirow{6}{*}{$\begin{array}{l}\text { SMP } \\
\text { KD: } 3.1 \\
\text { Membuat } \\
\text { generalisasi } \\
\text { dari pola } \\
\text { pada barisan } \\
\text { bilngan dan } \\
\text { barisan } \\
\text { konfigurasi } \\
\text { objek } \\
4.1 \text { menye- } \\
\text { lesaikan } \\
\text { masalah } \\
\text { yang } \\
\text { berkaitan } \\
\text { dengan pola } \\
\text { pada barisan } \\
\text { bilangan dan } \\
\text { barisan } \\
\text { konfigurasi } \\
\text { objek. }\end{array}$} \\
\hline Singa & $\begin{array}{l}2.8 \\
\ldots\end{array}$ & $\begin{array}{c}a=2, \\
b=6 \\
U n=2+(n-1) 6\end{array}$ & \\
\hline Gorila & $\begin{array}{l}3,9 \\
\ldots\end{array}$ & $\begin{array}{c}a=3 \\
b=6 \\
U n=3+(n-1) 6\end{array}$ & \\
\hline Renggo & $\begin{array}{l}4,10, \\
\cdots\end{array}$ & $\begin{array}{c}a=4 \\
b=6 \\
U n=4+(n-1) 6\end{array}$ & \\
\hline $\begin{array}{l}\text { Kelelawa } \\
\mathrm{r}\end{array}$ & $\begin{array}{l}5,11, \\
\ldots\end{array}$ & $\begin{array}{c}a=5 \\
b=6 \\
U n=5+(n-1) 6\end{array}$ & \\
\hline Capung & $\begin{array}{l}6,12, \\
\ldots\end{array}$ & $\begin{array}{c}a=6 \\
b=6 \\
U n=6+(n-1) 6\end{array}$ & \\
\hline
\end{tabular}

Selain itu kearifikan lokal budaya juga dapat diintegrasikan melalu permainan mejikihibinu. Sama halnya dengan permainan Nasi Goreng Kecap, penelitian ini hanya menggunakan bagian kedua dari permainan tradisional mejikuhibiniu yang di integrasikan ke dalam materi pola bilangan siswa kelas delapan SMP
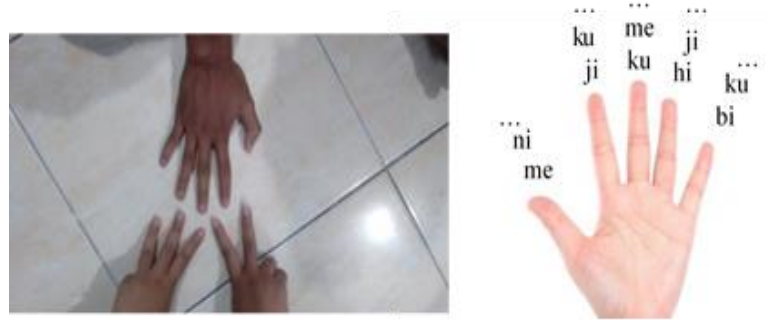

Gambar 3. Cara Memainkan Permainan Mejikuhibiniu

Tahap kedua permainan mejikuhibiniu dimulai dengan masing-masing pemain menjulurkan jari dengan bebas, seperti terlihat pada Gambar 3. Menurut Gambar 3 , merah, biru, dan kuning merentangkan 3 jari jari, 2 jari, 
dan 5 jari. Masing-masing pemain mulai menunjuk dengan jarinya yang terulur dan berkata "mejikuhibinu". Setiap suku kata mewakili jari. Setelah proses penamaan selesai, suku kata terakhir adalah "ku", yang berarti kuning harus meninggalkan permainan. Jika diperhatikan, setiap nama berubah menurut pola yang biasa, yaitu ada 7 nama yang berdekatan dengan nama yang sama.

Tabel 2. Pola Barisan Bilangan Permainan

\begin{tabular}{|c|c|c|c|}
\hline \multicolumn{4}{|c|}{ Mejikuhibiniu } \\
\hline $\begin{array}{c}\text { Mejiku } \\
\text { hiniu }\end{array}$ & $\begin{array}{l}\text { Bany } \\
\text { ak } \\
\text { jari }\end{array}$ & Bentuk umum & $\begin{array}{l}\text { Kompeten } \\
\text { si Dasar } \\
\text { (KD) }\end{array}$ \\
\hline Merah & $\begin{array}{l}1,8, \\
\ldots\end{array}$ & $\begin{array}{c}a=1 \\
b=7 \\
U n=1+(n-1) 7\end{array}$ & $\begin{array}{l}\text { SMP } \\
\text { KD: } 3.1 \\
\text { Membuat }\end{array}$ \\
\hline Jingga & $\begin{array}{l}2.9, \\
\ldots\end{array}$ & $\begin{array}{c}a=2, \\
b=7 \\
U n=2+(n-1) 7\end{array}$ & $\begin{array}{l}\text { generalisas } \\
\text { i dari pola } \\
\text { pada }\end{array}$ \\
\hline Kuning & $\begin{array}{l}3,10, \\
\ldots\end{array}$ & $\begin{array}{c}a=3 \\
b=7 \\
U n=3+(n-1) 7\end{array}$ & $\begin{array}{l}\text { barisan } \\
\text { bilngan } \\
\text { dan barisan }\end{array}$ \\
\hline Hijau & $\begin{array}{l}4,11, \\
\ldots\end{array}$ & $\begin{array}{c}a=4 \\
b=7 \\
U n=4+(n-1) 7\end{array}$ & $\begin{array}{l}\text { konfigurasi } \\
\text { objek } \\
4.1 \text { menye- }\end{array}$ \\
\hline Biru & $\begin{array}{l}5,12, \\
\ldots\end{array}$ & $\begin{array}{c}a=5 \\
b=7 \\
U n=5+(n-1) 7\end{array}$ & $\begin{array}{l}\text { lesaikan } \\
\text { masalah } \\
\text { yang }\end{array}$ \\
\hline Nila & $\begin{array}{l}6,13, \\
\ldots\end{array}$ & $\begin{array}{c}a=6 \\
b=7 \\
U n=6+(n-1) 7\end{array}$ & $\begin{array}{l}\text { Derkaitan } \\
\text { dengan } \\
\text { pola pada }\end{array}$ \\
\hline Ungu & $\begin{array}{l}7,14, \\
\ldots\end{array}$ & $\begin{array}{c}a=7 \\
b=7 \\
U n=7+(n-1) 7\end{array}$ & $\begin{array}{l}\text { bilangan } \\
\text { dan barisan } \\
\text { konfigurasi } \\
\text { objek. }\end{array}$ \\
\hline
\end{tabular}

Dalam hal ini, permainan tradisional Nasi Goreng Kecap dan Mejikuhibiniu sebagai sumber belajar dalam menyampaikan materi pembelajaran pola bilangan. Diharapkan dengan mengintegrasikan materi pola bilangan melalui permainan tradisional Nasi Goreng Kecap dan Mejikuhibiniu dapat menumbuhkan rasa cinta terhadap budaya Indonesia.

\section{Kesimpulan}

Berdasarkan hasil dan pembahasan, permainan tradisional Nasi Goreng Kecap dan Mejikuhibiniu memuat konsep pola bilangan. Permainan nasi goreng kecap dan mejikuhibiniu bisa dijadikan sebagai media untuk membantu pembelajaran matematika lebih menarik, efektif, dan membuat siswa lebih aktif dalam pembelajaran sehingga mampu meningkatkan kemampuan berpikir kreatif siswa. Permainan nasi goreng kecap dan mejikuhiniu juga dapat melatih kemampuan berpikir (kognitif), kemampuan berhitung, mengasah keterampilan sosial, dan dapat meningkatkan kepercayaan diri.
Dengan demikian melalui permainan Nasi Goreng Kecap dan Mejikuhibiniu dapat dibuat suatu pembelajaran yang terintegrasi materi pola bilangan. Dengan adanya pembelajaran yang integratif melalui permainan tradisional Nasi Goreng Kecap dan Mejikuhibiniu siswa dapat belajar dengan senang sekaligus dapat melestarikan budaya.

\section{Daftar Pustaka}

Abdur Rahman As'ari et al. (2017). Matematika SMP/MTs Kelas VIII Semester 2. Kementrian Pendidikan dan Kebudayaan.

Aprilia, E. D., Trapsilasiwi, D., \& Setiawan, T. B. (2019). Etnomatematika Pada Permainan Tradisional Engklek Beserta Alatnya Sebagai Bahan Ajar. 10.

Dahlan, J. A., \& Permatasari, R. (2018). Development of Instructional Materials Based On Ethnomathematic in Mathematics Learning in Junior High School. JNPM (Jurnal Nasional Pendidikan Matematika), 2(1), 133-150. https://doi.org/http://dx.doi.org/10.33603/jnpm. v2i1.987

Fahrurrozi, M. (2015). Pembelajaran Berbasis Budaya: Model Inovasi Pembelajaran dan Implementasi Kurikulum Berbasis Kompetensi. In Prosiding Seminar Nasional dan Call For Papers Pendidikan Karakter dalam Pembelajaran Bisnis dan Manajemen.

Leal Vasquez, E. (2017). Ethnomathematics as an Epistemological Booster for investigating Culture and Pedagogical Experience with theYoung Offender orPrison School Communities. Journal of Education and Human Development, 6(1), https://doi.org/10.15640/jehd.v6n2a13

Lubis, S. I., Mujib, A., \& Siregar, H. (2018). Eksplorasi Etnomatematika pada Alat Musik Gordang Sambilan. Edumatika : Jurnal Riset Pendidikan Matematika $1(2)$, https://doi.org/10.32939/ejrpm.v1i2.246

Misnasanti, M., Dien, C. A., \& Astuti, A. D. (2018). Internalisasi Nilai Kearifan Lokal Pada Pembelajaran Matematika Di Era Post-Modern. Seminar Nasional Pendidikan ..., 158-162. http://seminar.uad.ac.id/index.php/sendikmad/ar ticle/view/33

Munawaroh, H. (2017). Pengembangan Model Pembelajaran dengan Permainan Tradisional Engklek Sebagai Sarana Stimulasi Perkembangan Anak Usia Dini. Jurnal Obsesi : Jurnal Pendidikan Anak Usia Dini, 1(2), 86. https://doi.org/10.31004/obsesi.v1i2.19

Nusantara, T., \& Rahardjo, S. (2017). Ethnomathematics In Arfak West PapuaIndonesia Numeracy Of Arfak. International Journal of Scientific \& Technology Research, 06(09), 325-327. 
Prahmana, R. C. (2017). Design Research: (Teori dan Implementasinya: Suatu Pengantar).

Pratiwi, J. W., \& Pujiastuti, H. (2020). Eksplorasi Etnomatematika pada Permainan Tradisional Kelereng. Jurnal Pendidikan Matematika Raflesia, 5(2), 1-12. https://ejournal.unib.ac.id/index.php/jpmr/article /view/11405

Rohmatin, T. (2020). Etnomatematika Prmainan Tradisional Congklak Sebagai Teknik Belajar Matematika. Prosiding Konferensi Ilmiah Dasar, 2, 144-150.

Rosikhoh, D., \& Abdussakir, A. (2020). Pembelajaran Pola Bilangan melalui Permainan Tradisional Nasi Goreng Kecap. Jurnal Tadris Matematika, 3(1), 43-54. https://doi.org/10.21274/jtm.2020.3.1.43-54

Rusiana, \& Nuraeningsih. (2016). Teaching English to Young Learners Through Traditional Games.
English Education: Journal of English Teaching and Research, 10(2), 193-200. https://journal.unnes.ac.id/nju/index.php/LC/arti cle/view/5729/4602

Susanti, E. (2020). Eksplorasi Etnomatematika Konsep Operasi Hitung dalam Permainan Tradisional Kempreng. Suska Journal of Mathematics Education, 6(1), 1-8. http://ejournal.uinsuska.ac.id/index.php/SJME/article/view/10025

Tanudirjo, D. A. (2003). Warisan Budaya untuk Semua: Arah Kebijakan Pengelola Warisan Budaya Indonesia di Masa Mendatang. 19-23.

Verner, I., Massarwe, K., \& Bshouty, D. (2019). Development of competencies for teaching geometry through an ethnomathematical approach. Journal of Mathematical Behavior, 56(May),

100708 . https://doi.org/10.1016/j.jmathb.2019.05.002. 